\title{
The State Of Entrepreneurship Education At Tertiary Institutions In The Western Cape
}

\author{
Pradeep Brijlal, (Email: pbrijlal@uwc.ac.za), University of the Western Cape, South Africa
}

\begin{abstract}
This paper summarizes, analyses the offerings and gaps on entrepreneurship education at four tertiary institutions in the Western Cape. Most of the offerings were knowledge based. Some of the participants on the programmes were exposed to real businesses and hence had experiential learning. The individual as an entrepreneur seemed to be overlooked. As tertiary institutions' culture changes it will become more important to understand students' entrepreneurial needs in order that there is institutional "fit" between higher education offerings and the need for students. The various institutions should collaborate on a frequent basis to establish the needs and share resources. This can include services like consulting, mentoring, training and research by experts in the field and share their experiences with other lecturers and trainers.
\end{abstract}

Keywords: entrepreneurship education; tertiary institutions; Western Cape

\section{INTRODUCTION}<smiles></smiles>
tudents graduating from tertiary institutions enter an environment that is changing and unstable. Technology and contingent factors are daily changing the world of opportunity. Students today increasingly recognize that in the current economic climate most jobs are rarely "for life". The world of employment is changing, Fallows and Steven (2000) state "Permanence and longevity is no longer a significant feature of career paths: traditional paths have disappeared". This widely held view has led to the speculation that there will be continuing growth in self-employment as a career option for individuals at different stages in their lives. There is now a widespread recognition that entrepreneurship is the engine that drives the economy of most nations. unemployment.

It seems that in South Africa the need for entrepreneurial development is emphasized by the high levels of

According to Niyonkuru (2005) a recent report by the European Commission in 2004 regards education as an important means to create a more entrepreneurial mindset among young people and it asserts that promoting entrepreneurial skills and attitudes provides benefits to society even beyond their application to new business ventures. It has been documented that most new jobs arise from entrepreneurial small firms. In most universities in the USA, entrepreneurship courses are offered at both the undergraduate and graduate levels. A survey conducted by Wilson (2004) reveals that entrepreneurship courses remain primarily electives at European universities at both the undergraduate and post graduate levels.

Driver et al. (2001) in their annual Global Entrepreneurship Monitor (GEM) reports that there is an overall lack of entrepreneurship elements in the education system in South Africa. Some of the factors that contribute towards entrepreneurial culture are: attitudes towards entrepreneurship, business role models, negative mindsets towards confidence, initiative and creativity and negative perception towards entrepreneurship as a career choice.

The economic structure in South Africa is well served by tertiary institutions in that they provide a resource pool for big businesses, in general. In the process, however, a student mind set has been entrenched that favors employment in the big businesses. With our economy being in transition, just over ten years into our new 
democracy, small and medium businesses are accounting for an increasingly greater proportion of economic activity, as such tertiary institutions need to redefine their role in the economy and in society.

The Business Day (2007) reports that the Centre for Innovation and Entrepreneurship at the UCT Graduate School of Business, shows that South Africa's position on the global entrepreneurship ranking continues to deteriorate relative to other countries, particularly when compared to similar emergent economies. This is despite improved macro-economic conditions in the country. This year, South Africa was ranked 30th out of 42 countries with just 5.29\% of its population involved in Total Early-stage Entrepreneurship (TEA) activities. This is down from $9.4 \%$ in 2001, the first year that it took part in the survey. By contrast, top performer Peru scores a $40 \%$ TEA. This downward trend spells trouble for the South African economy in the long term. To address the situation, GEM recommends that policies around entrepreneurship should focus on improving individual entrepreneurial capabilities on all levels - be that through education and relevant skills training or by creating better mechanisms of support.

There is a positive relationship between education and business creation, as acknowledged by Luthje and Frank ( 2002); Charney and Libecap (2000); Robinson and Sexton (1994). They also indicated that entrepreneurship can be taught and that education can enhance entrepreneurial skills, competencies and attitudes ( Niyonkuru:2005).

This paper provides useful insights into the state of entrepreneurship education for a range of role players, including policymakers, academics, educational institutions and the public in general. It could also assist tertiary institutions in understanding the shortcomings of current entrepreneurship programmes and raise awareness about developing suitable entrepreneurship programmes to prepare students for entrepreneurship as a career option.

\section{AIM AND OBJECTIVES}

The aim of this article is to explore what is offered in entrepreneurship education at tertiary institutions in the Western Cape and to suggest improvements for the curriculum.

\section{Objectives}

- $\quad$ To list and compare the offerings in entrepreneurship education at 4 tertiary institutions in the Western Cape.

- To analyze the entrepreneurship offerings.

- $\quad$ To suggest a way forward for improvement.

\section{REASEARCH METHODOLOGY}

Information on the offerings of entrepreneurship education was retrieved from the website of the various institutions, prospecti and personal interviews with some of the stakeholders who offer entrepreneurship education. An extensive literature study was done in order to describe some of the findings and success factors of entrepreneurship education.

\section{OFFERINGS OF ENTREPRENEURSHIP COURSES IN THE WESTERN CAPE}

Three universities and one technical institution were surveyed in terms of the offerings on entrepreneurship education. A summary of what was offered is provided. These institutions include: University of the Western Cape, University of Cape Town, University of Stellenbosch and Cape Peninsula University of Technology .

\section{UNIVERSITY OF THE WESTERN CAPE}

\section{Department Of Management}

The department offers an Enterprise Management stream, and an Enterprise Development Management. Their innovative professional management programmes are targeted at mature learners who seek to advance their careers in 
management, with special programmes developed for owners of small to medium enterprises wishing to grow their businesses. The courses are offered in years two and three of the undergraduate programme. These include:

\begin{tabular}{|c|c|}
\hline Second year & Third year (electives) \\
\hline Starting a business (theory) & Business law for SMEs \\
Starting a business (Practice) & Finance for growing enterprise \\
Operating the Small Business (Practice) & Continuous improvement for SME manufacturers \\
Harvesting the enterprise & Strategic linkages for SMEs \\
& Global markets and exports \\
& SME management \\
\hline
\end{tabular}

\section{Entrepreneurial Development Unit (EDU), UWC}

The EDU, as part of the Department of Management, seeks to promote and develop the management capabilities of small to medium enterprises in order to contribute to the growth of businesses, competitiveness and economic development. The focus of the unit is primarily on the small to medium entrepreneurship sector, including owner/managers of small to medium enterprises and governmental and non-governmental organizations that provide services to (Small, medium and micro-enterprises) SMME's.

\section{UNIVERSITY OF CAPE TOWN}

\section{The Graduate Business School At The University Of Cape Town (GSB UCT)}

The Graduate School of Business offers various short programmes for entrepreneurs or potential entrepreneurs. Two short courses include build your own business and entrepreneurship for SMME's :

\section{Build Your Own Business}

This course is for entrepreneurs who are considering starting their own businesses. The objectives are to provide participants with the skills necessary and the determination to either start a new business or develop a new project, in order to realize their dreams. The following key issues are considered in the programme:

- What is entrepreneurship and what are the success and failure factors for small to medium businesses.

- $\quad$ Creating an idea

- $\quad$ Strategic business planning

- $\quad$ Starting a business

- $\quad$ Raising funds for your venture

- Internationalization

- $\quad$ Team building

- $\quad$ Black economic empowerment

- $\quad$ Adding value and selling your business

By the end of the six day programme, participants are expected to have the information and skills to be able to prepare a business plan for a new venture and will fully understand how and where to raise finance.

\section{Entrepreneurship For SMMES}

This programme is targeted for owners and managers of SMMEs that have been in operation for a minimum of one year, or owners and managers looking for practical and innovative growth strategies for their enterprises. The objectives of the programme are: 
- $\quad$ To provide participants with an ability to identify whether their business is ready for expansion

- Help the participant break out of the crisis management mode and to direct effort in terms of defined economic and operational goals

- $\quad$ To provide participants with the questions that need to be answered, the steps that need to be taken and the pitfalls to be avoided to ensure a successful growth strategy

By the end of the three day programme participants are expected to focus on the future and to provide networking opportunities and sharing of ideas with other SMME owners.

\section{The Centre For Innovation And Entrepreneurship (CIE)}

This centre which runs a number of entrepreneurial electives on the UCT MBA program that are designed to deliver practical skills via experiential learning as well as executive short courses. The centre is organized around three distinct, but mutually reinforcing sets of activities, which include, teaching and material development, research and public policy, and business creation and growth. In an attempt to outreach to the main campus of UCT, this program was started to introduce entrepreneurship to final year undergraduate students. A course in Venture Planning is offered to students in the following departments of UCT: Chemical, Mechanical and Electrical Engineering, Molecular \& Cell Biology, Computer Science and the Department of Socio Economic Development.

This centre plays a role in terms of business creation and development in the Western Cape. The CIE aims to enhance innovation and entrepreneurial capacity in South Africa's businesses to help them in their drive for international competitiveness. Furthermore, the course is run in such a way that students work in a consulting capacity with businesses operated by entrepreneurs from previously disadvantaged communities.

The CIE also runs the following Short Course for Entrepreneurs, which is run over four days. The course is aimed at providing entrepreneurs with important business training to enhance the profitability and growth of their small businesses. The Short course comprises the following:

\begin{tabular}{|c|c|c|c|}
\hline \multicolumn{2}{|c|}{ Accounting } & Marketing & Operations \\
\hline $\begin{array}{l}\text { Record keeping } \\
\text { Financial reports } \\
\text { Control systems } \\
\text { Cash is King }\end{array}$ & $\begin{array}{c}\text { Costing } \\
\text { Break-even analysis } \\
\text { Time value of money } \\
\text { Sources of finance }\end{array}$ & $\begin{array}{c}\text { What is marketing? } \\
\text { What are you marketing? } \\
\text { Understanding the marketing mix } \\
\text { Identify your product and market and USP } \\
\text { Putting together your marketing plan }\end{array}$ & $\begin{array}{l}\text { Operational considerations } \\
\text { Internal infrastructure } \\
\text { People management }\end{array}$ \\
\hline
\end{tabular}

\section{The School Of Management Studies}

The School of Management Studies under the Faculty of Commerce, offers a Postgraduate Diploma in Enterprise Management (PDEM). The diploma makes extensive use of action learning as an effective way to learn about organizations. Students, in small groups, are required to set up and run real businesses for the duration of the year of study. This practical side of the course is balanced by sound academic theory taught in a variety of modules throughout the year. In this way students are given opportunities to implement and evaluate theory in their own businesses. While students are running their own business (Genesis Project), they concurrently attend courses that have been developed both specifically for PDEM, as well as for other diplomas in management. The first half of the year concentrates mainly on general business courses (Entrepreneurial strategies, Finance, Business in context, Marketing and Business computing). In the second half of the year the focus falls on the area of specific study, in this case, enterprise management. Courses here include: Management Theory, The Politics of Enterprise, People Management and Development and Information Technology and Marketing. Students also attend a course in Business communication and Career Development which develops other critical skills. The diploma accepts students with an undergraduate degree from various disciplines, such as medicine, music, engineering and architecture. 


\section{UNIVERSITY OF STELLENBOSCH (US)}

\section{Faculty Of Economic And Management Sciences}

The above faculty offers Entrepreneurship and Innovation Management comprising Introduction to Entrepreneurship, Small Business Management, Creativity and Innovation Management and Strategic and Innovation management. These courses are taken in second and third years of study.

\section{Centers And Other Units}

Various centers and a company at US act as a focal points for specific disciplines. These entities undertake specialized research; publish articles and journals, and offer workshops, programs, conferences, and information sessions.

\section{USB Executive Development Limited (USB-ED)}

The USB-ED has experienced steady shift from public programs to develop their management pool in intellectual capital. USB-ED has its own advisory committee and works in close collaboration with the business community in order to produce relevant program material. Company specific programs are co-designed with the company involved.

\section{University Of Stellenbosch Matie Community Service}

The Matie Community Service centre has a program in Basic Skills is targeted mainly at women entrepreneurs and includes training on the various aspects of business such as market research, financial planning and management. The Business skills training program is also targeted at people with disabilities and potential and existing entrepreneurs who happen to be physically disabled.

\section{CAPE PENINSULA UNIVERSITY OF TECHNOLOGY (CPUT)}

The entrepreneurial programmes at CPUT are structured to provide participants with an understanding of the basic principles of managing small and medium businesses and also offered to graduates with sound hands on management skills. CPUT offers a National Diploma in Entrepreneurship. The aim of the course is to enable graduates to contribute to economic upliftment and job creation by starting their own businesses, assisting others to start businesses, or to manage existing businesses. The programme comprises:

\begin{tabular}{|l|l|l|}
\hline \multicolumn{1}{|c|}{ First year } & \multicolumn{1}{|c|}{ Second year } & \multicolumn{1}{c|}{ Third year } \\
\hline Small business management 1 & Small Business management 11 & Small business management 111 \\
Marketing 1 & Marketing 11 & Small Business management \\
Communication 1 & Production Management 1 & Practice 111 \\
End-user computing 1 (module 1) & End-User Computing 1 (module 2) & Administrative management 1 \\
Select one of the electives: & Organizational Effectiveness 1 & Labor relations and law 11 \\
Financial Management 1 or & Select one of the electives: Costing and & Select one of the electives: \\
Personal Selling 1 & Estimating or Financial Management 11 & Financial Management 111 or \\
& & Credit Control 1 \\
\hline
\end{tabular}

CPUT also offers other short courses at NQF (National Qualifications Framework) level 7 and NQF level 4. These include:

\section{Establishing A Small Business (NQF level 7)}

The aim of this course is to equip managers and entrepreneurs with the skills and abilities to manage the day-to-day operations of a small to medium sized business and to be able to design an Operational Management 
Plan and compile a Business Plan. It is targeted at: any person managing or planning to establish a small or medium sized business, SMME Owners, Guest House / Restaurant Owners, Tourist Guides, New Graduates and Crafters. The core syllabus comprises the following:

- $\quad$ Design an effective service or product.

- Design an effective operations and purchasing network.

- Design an operation system in terms of the goals and objectives of the business.

- $\quad$ Activities of the purchasing function apply them in a Business.

- $\quad$ Design a Production and Purchasing Management plan for the Business.

- $\quad$ Goals and objectives of a Business Plan.

- $\quad$ Compile an appropriate Business Plan for an SMME

The above course runs for three days, with 22.5 contact hours.

\section{Small Business Development: NQF Level 4}

The aim of this course is to equip entrepreneurs, small business owners, and emerging BEE business owners with necessary financial literacy / business skills for future success. The course is aimed at Entrepreneurs, Small Business Owners and Emerging BEE business owners. The syllabus comprises:

- Develop a business plan for a small business

- Investigate the possibilities of establishing and running a small business(SMME)

- Investigate ways of managing financial risk in ones' own lives

- Interpret basic financial statements

- $\quad$ Describe the basic principles of personal income taxes

The course is run over two semesters with two sessions of two hours per week.

\section{Entrepreneurship Unit For Disadvantaged Communities}

This unit was established in 2003, the Unit of life long Learning uplifts and empowers disadvantaged communities through learning. Its goals are as follows:

- $\quad$ Promoting lifelong learning by training adults in business informatics and related fields.

- Establishing an entrepreneurial enterprise on the main campus where members of the technikon and community learn about the principles of entrepreneurship.

- Attracting visitors and tourist to the technikon to view entrepreneurship in all its phases.

\section{TABEISA Enterprise Centre (TEC)}

TEC's objectives are to help students and people from community to create new businesses, manage and grow their business as well as developing community projects to create job opportunities. The following services are provided to SMMEs

- $\quad$ Business planning-market analysis-cash flow and budgeting

- Registration of businesses

- $\quad$ Access to finance

- $\quad$ After care mentoring

- $\quad$ Training and development support

TEC forges partnerships with organizations working in the fields of business support and advice and community economic development in order to complete and enhance their work. 


\section{ANALYSIS OF ENTREPRENEURSHIP OFFERINGS IN THE WESTERN CAPE}

This paper is concerned with the offerings of entrepreneurship education at the different tertiary institutions. While education programmes are aimed at different target markets and levels of education they all have as their core the concept of stimulating entrepreneurial activity in some or other way. Solomon et al. (2002), cited in Pretorius et al (2005), confirm the positive role of teaching entrepreneurial and small business management skills for new venture creation and success.

It would seem that small business management courses and entrepreneurship courses are used interchangeably. Small business management courses provide students with the management of a business, associated with managing and operating post start-up companies, including setting goals and objectives, leading, planning, organizing and controlling an organization. Winslow, Solomon and Tarabishy (1999) in Niyonkuru, 2005) declare that entrepreneurship courses emphasize information in which the principle objectives of the entrepreneur are the creation and the development of a new venture with an emphasis on profitability and rapid growth and expedient exit strategies. Most of the courses offered at the four institutions focus their learning content on the concepts of entrepreneurship and small business management. The tertiary institutions have various types of entrepreneurship related programmes ranging from specialized courses up to a masters level, targeting different groups of existing and potential entrepreneurs. The duration of the courses offered ranged from a few hours to a few years. The programmes have different goals in terms of context as well as outcome.

Although the MBA programmes at the universities of Cape Town and Stellenbosh had some components of entrepreneurship education, the focus was more on improving business than on start-ups. The MBA at US turns out graduates with both practical business and intellectual depth through offering balanced courses that result in specialization opportunities to help students refine their preferred competencies, thereby preparing them to operate with confidence in their particular field. UWC offers a major in entrepreneurship, with the option of pursuing honours in the Enterprise Development Stream.

Entrepreneurial development is critical to the integration of vast numbers of youths into the South African economy. As a practical subject, it provides the opportunity for learners to develop skills that can be translated into a meaningful living. The subjects and skills taught at some of the institutions do not appear to encourage learners to become active agents of their own destiny through developing qualities such as independence, risk taking, self motivation and innovation.

Tertiary institutions play an important role in developing entrepreneurial society in that they instill in their students at graduate and post-graduate level a sense of understanding of risks and rewards of business creation and its destruction. They can also play a role in developing entrepreneurial traits in students and can provide the necessary support for entrepreneurs as well providing legitimacy to their endeavors. The various institutions have structured programmes for the various target markets and the understanding of risks and rewards of being an entrepreneur did not seem to be part of the programmes. Entrepreneurship students are assumed to expect to learn about what it takes to succeed in entrepreneurial endeavors.

Although the learning programmes include the best knowledge and skills (content) about starting a business as its output, there is no guarantee that the students will act entrepreneurial unless their mindset, willingness to take risks, confidence, attitude and behavior have been influenced as well (Pretorius et al, 2005). The transfer of knowledge and skills may be effective. However changing the behaviour to engage in start-up process is what really matters and which seems to be lacking at the institutions researched.

The programmes are predominantly geared towards functional or business skills. Little emphasis is placed on motivation or the entrepreneur as a person and entrepreneurial skills. Typically motivation and entrepreneurial skills would be elements of human skills while business skills and the business plan utilization are elements of venture skills. Motivation of the learner is probably the toughest challenge to the facilitator to achieve compared to business skills and reading the environment. The institutions discussed cater more for persons with a certain literacy level and equips them with knowledge and allows them to experience entrepreneurship by doing case studies and 
assignments and writing exams and tests. Most of them also conduct research that is related to entrepreneurship.

Based on the information from the various institutions, it seems that an entrepreneurial culture is not really boosted in tertiary institutions that churn out would-be bureaucrats rather than calculated risk takers. Institutions did not seem to be networking or sharing resources. Some institutions did not offer entrepreneurship education to final years in other disciplines or faculties, which could turn out self employed graduates.

Assessments were in the form of assignments, formal exams and questionnaires. There was little evidence of institutions tracking students after completing certain programmes in order to determine the impact of their programmes in terms of start-ups, improvement and sustainability of the businesses. Students need time to build and create opportunities and gain a sense of accomplishment. Tertiary institutions typically do not provide students with the opportunity to do this within an entrepreneurial context or environment, particularly the long-term incubation and the development of a viable business idea - an element that is recognized as essential to the venture creation process.

Entrepreneurs generally learn most from other entrepreneurs through sharing ideas, making useful social contacts, an informal process that requires neither state intervention nor taxpayers' money. Some of the institutions were not involving successful entrepreneurs or role models in the curriculum. Education and skills are inherently longer-term strategies. It is useful to complement them with interventions to improve national regulatory and the institutional environment within which the business operates, in the short term. Specifically, business training programmes have greater prospects for success when they are moulded to meet the needs of the entrepreneurs directly, in specific sectors, niches, places or technical circumstances. Most of the programmes offered by the institutions were short courses or electives and this may have a limiting effect on their success as entrepreneurs.

While students still need to develop their business skills and understanding, there was not much attention paid to the development of entrepreneurial skills, attributes and behaviors. This means introducing modules and courses specifically designed to develop students' awareness and characteristics of the entrepreneur.

\section{THE WAY FORWARD}

In South Africa, as our tertiary institutions and state agencies learn more about SMMEs and about each other, they will need to continue to redefine their roles and adjust their programmes. Tertiary institutions have the infrastructure to provide the arena and the networking systems to bring people together.

Collins et al (2004) provides a review of the gap between student's entrepreneurial needs and aspirations and the entrepreneurship education offerings within higher education systems in the United Kingdom. They highlighted some areas where tertiary institutions might concentrate on changing current policies, practices and offerings, including:

- Seeking more detailed information from students and using this information to inform curriculum development;

- $\quad$ Building cumulative pre-incubation time into the curricula to allow students to build and develop a business idea;

- $\quad$ Preparing students for "risk" and "ownership"; and

- $\quad$ Providing entrepreneurial experiences for students; making it easier for students to "drop-in" and "dropout" of education after graduation.

As tertiary institutions' culture changes it will become more important to understand students' entrepreneurial needs in order that there is institutional "fit" between higher education offerings and the need for students. "The totality of the experience that students gain at higher education is, and will be, influenced by many factors, including the prior experiences they have had in education; their personal aspirations for the future; their expectations concerning their life while at university; and how their experience at university supports their future aspirations" (Collin et al, 2004). 

following:

Tertiary institutions can contribute in creating entrepreneurial skills by providing, amongst others, the

- $\quad$ The knowledge, skills and the attitudes that its graduate posses (the objective being effect a change in mind set of students from potential employees to employers).

- Equipping students with practical business skills and facilitate experiential learning and exposure opportunities with the small, medium and micro enterprise sector that will be mutually beneficial

- Having experts, for example successful entrepreneurs or lecturers, who will teach these graduates and also be involved in wealth generation activities and they must facilitate opportunities for the student body (SRC) to become involved as well.

Friedrich and Visser (2004) offer the following recommendations for improvement of entrepreneurship education:

- $\quad$ Future training: future entrepreneurship training must be based on practical, "hands-on" experiences;

- $\quad$ Length of training courses: Short training courses in entrepreneurial training as found in business schools, do not have the same results as found in training courses of longer duration. This recommendation is based on their finding that the changing of attitudes do not easily occur over a short period of time; rather, a longer period of time is required to influence this process which is especially true in larger groups;

- $\quad$ Training over a longer time period impacts positively on the outcome.

Focus on formal education obscures the hidden curriculum of family experience and exposure to entrepreneurial role models which also contribute. Showering general formal training on would-be entrepreneurs can be less helpful than hoped. The process of developing skills in small enterprises ought to be of a less formal and more hands-on approach. This is also supported by Pretorius (2001) who reported that the element usually associated with more successful approaches relates to the involvement and the participation of the learner and the learning process.

The aim of entrepreneurial programmes should be the development of a truly student centered learning experience that delivers measurable outcomes for future entrepreneurs and innovative employees. The programmes should be offered to all faculties, in order to encourage self-employment after graduating. The programmes should include, amongst others, personal and enterprise development objectives, as listed in table 1:

Table 1: Personal and enterprise development objectives

\begin{tabular}{|c|c|}
\hline Personal development & Enterprise development \\
\hline Concept of entrepreneurship & Identifying and evaluating opportunities \\
\hline Characteristics of an entrepreneur & Commercializing a concept \\
\hline Value of entrepreneurship & Developing entry strategies \\
\hline Creativity and innovation skills & Constructing a business plan \\
\hline Entrepreneurial and ethical self-assessment & Finding capital \\
\hline Networking, negotiating and deal-making & Initiating the business \\
\hline Communication and problem solving skills & Growing the business \\
\hline Critical thinking and assessment skills & Harvesting the business \\
\hline
\end{tabular}

Source: adapted Verser and Gartner (2001)

The growing literature on entrepreneurship education tends to argue that a different learning environment is required to support the study of entrepreneurship within a university setting. Essentially, a teaching style that is action-oriented, encourages experiential learning, problem solving, project-based learning, creativity, and is supportive of peer evaluation (Jones and English, 2004). 
According to the GEM report (2006) South Africa needs more start-ups and entrepreneurs to make it work, as well as a higher level of business acumen and involvement. But as entrepreneurship is not a natural process in South Africa at the moment, it needs to be managed in a more formal and integrated manner until it becomes an ordinary aspect of our daily existence. If a coordinated and focused ways of supporting entrepreneurship can be developed and maintained over time, the chances of creating and maintaining a sustainable entrepreneurial South Africa should be high.

Research also needs to be done in tracking entrepreneurs and assessing their performances over a longer term, in order to establish the effectiveness of the programmes offered by the institutions. Entrepreneurship teaching should be about entrepreneurship, which is based on the construction and transfer of knowledge about the field and for entrepreneurship, which focuses on the learning experience and the development of competencies, skills, aptitudes and values.

\section{CONCLUSION}

This paper has summarized the offerings on entrepreneurship education at four tertiary institutions. Most of the offerings were knowledge based. Some of the participants on the programmes were exposed to real businesses and hence had experiential learning. The individual as an entrepreneur seemed to be overlooked. As tertiary institutions' culture changes it will become more important to understand students' entrepreneurial needs in order that there is institutional "fit" between higher education offerings and the need for students.

The various institutions should collaborate on a frequent basis to establish the needs and share resources. This can include services like consulting, mentoring, training and research by experts in the field and share their experiences with other lecturers and trainers. It should be borne in mind that behaviors of current and previous entrepreneurs are not likely to provide a complete answer to what future entrepreneurs need to do in order to be successful. A prospective entrepreneur may benefit from many types of knowledge, which are taught in tertiary institutions. The programmes should include, amongst others, personal objectives and enterprise development objectives.

\section{REFERENCES}

1. Brown, W \& Galloway, L 2002. Entrepreneurship education at university: a driver in the creation of high growth firms? Education and Training Journal. 44(8/9): 398-405.

2. Collins, L., Hannon, P D. \& Smith, A 2004. Enacting entrepreneurial intent: the gaps between student needs and the higher education capability. Education and Training Journal. 46(8/9): 454-463.

3. Davies, T. A. 2001. Entrepreneurship development in South Africa: redefining the role of tertiary institutions in a reconfigured higher education system. South African Journal of higher education. 15(1):34-39.

4. Davies, T. A. \& Pillay, D. 2000. Small medium and micro enterprise (SMME) partnerships: a tertiary initiative to create a unique co-operative education model in commerce (The business clinic). South African Journal of higher education.14 (3):196-203.

5. Davies, J., Hides, M. \& Powell, J. 2002. Defining the development needs of entrepreneurs in SMEs. Education and Training Journal.44 (8/9): 406-412.

6. Dunphy, S. 1998. Definitions and usage of the term 'Entrepreneur': New direction for a global economy. Proceedings of the $33^{\mathrm{RD}}$ World Conference of the international Council for Small Business World Conference, Massachusetts. June 9-14. Kennesaw College. Georgia: Minuteman-ICBS.

7. English, J., Jones, C 2004. A contemporary approach to entrepreneurship education. Education and Training Journal. 46(8/9): 416-423.

8. Fallows, S. \& Steven, C. 2000.Building employability skills into the higher education curriculum: a university-wide initiative. Education and Training Journal. 42 (2): 75-82.

9. Friedrich, C. \& Visser, K 2004.The challenges of entrepreneurship education at university: Evidence from a longitudinal study survey. Working paper.UWC. 
10. Kirby, D.A. 2004. Entrepreneurship education: can business schools meet the challenge? Education and Training Journal. 46(8/9): 510-519.

11. Lascaris, R. \& Lipkin, M. 1993. Revelling in the Wild: Business lessons out of Africa. Cape Town: Human and Rousseau.

12. Maas, G. \& Herrington, M. 2006. Adult Population Questionnaire 2006. GEM Report, UCT Graduate School of Business.

13. Pretorius, M., Nieman, G. \& van Vurren, J. 2005. Critical evaluation of two models for entrepreneurial education: an improved model through intergration. International Journal of Educational Management.19 (5); 413-427.

14. Visser, K .1991.Access to success- a business simulation for high school learners. Southern African Journal for Entrepreneurship and Small Business. 3(1): 25-30.

15. Visser, K. 1995. Education for entrepreneurship. Proceedings of the International Conference on Technikon Research Development -the RDP challenge. Centre for Science Development and the Foundation for Research Development. Technikon Pretoria, June 26-27.

16. Verser, K. \& Gatner, W. 2001. University Entrepreneurship Programs, Lloyd Greif Center for Entrepreneurship Studies, Marshall School of Business, University of Southern California, Los Angeles.

17. White Paper, 1995. National Strategy for the Development and Promotion of Small Business in South Africa. Government Gazette. Cape Town: Government Printers. 357(16317).

\section{NOTES}


NOTES 